Hal. $76-90$

\title{
PENGARUH PEKERJAAN-KELUARGA DAN DUKUNGAN SOSIAL SERTA KECERDASAN EMOSIONAL TERHADAP STRES KERJA DAN KINERJA PERAWAT WANITA DI RSD dr. SOEBANDI JEMBER
}

\author{
Avira Rizqiana Yulia \\ Fakultas Ekonomi dan Bisnis, Universitas Jember \\ avirarizqiana@yahoo.com
}

\begin{abstract}
The purpose of this study among others, to analyze the effect of the work-family conflict, social support and emotional intelegence on work stress and job performance among female nurses in RSD dr. Soebandi Jember. This study was a research explanation. The study population was 237 female nurses of $R S D$ dr. Soebandi Jember. Sample was 120 people. Methods of data analysis used SEM. The result show that work-family conflict significantly influence work stress. Work-family conflict significantly influence job performance. Social support significantly influence work stress. Social support significantly influence job performance. Emotional intelegence significantly influence work stress. Emotional intelegence significantly influence job performance. Work stress significantly influence job performance.
\end{abstract}

Keywords: Work-family conflict, Social support, Emotional intelegence, Work stress, and Job performance

\begin{abstract}
Abstrak: Tujuan penelitian ini antara lain untuk menganalisis pengaruh konflik pekerjaan-keluarga dan dukungan sosial serta kecerdasan emosional terhadap stres kerja dan kinerja perawat wanita di RSD dr. Soebandi Jember. Penelitian ini merupakan explanation research. Populasi penelitian adalah 237 perawat wanita di RSD dr. Soebandi Jember. Sampel penelitian sebanyak 120 orang. Metode analisis data menggunakan SEM. Hasil penelitian menunjukkan bahwa konflik pekerjaan-keluarga berpengaruh signifikan terhadap stres kerja. Konflik pekerjaan-keluarga berpengaruh signifikan terhadap kinerja. Dukungan sosial berpengaruh signifikan terhadap stres kerja. Dukungan sosial berpengaruh signifikan terhadap kinerja. Kecerdasan emosional berpengaruh signifikan terhadap stres kerja. Kecerdasan emosional berpengaruh signifikan terhadap kinerja. Stres kerja berpengaruh signifikan terhadap kinerja.
\end{abstract}

Kata kunci: Konflik Pekerjaan-Keluarga, Dukungan Sosial, Kecerdasan Emosional, Stres Kerja dan Kinerja

\section{Pendahuluan}

Era globalisasi telah menciptakan tantangan bagi semua jenis industri untuk berkompetisi, termasuk industri dibidang layanan kesehatan, khususnya rumah sakit. Baik rumah sakit swasta maupun pemerintah bersaing demi menarik pasien dan memberikan pelayanan yang prima. Persaingan ini menuntut setiap rumah sakit untuk berusaha meningkatkan mutu pelayanan dan kinerja dalam memajukan bisnis rumah sakit yang dimilikinya, dan tentunya agar mampu bertahan dan diterima di kalangan masyarakat. Oleh karena itu 
diperlukan alternatif strategi bersaing yang tepat agar rumah sakit mampu bersaing dengan kompetitor lainnya. Salah satu strategi yang bisa diterapkan adalah strategi peningkatan kualifikasi sumber daya manusia-nya, baik dari staf medis maupun staf non medis.

Perawat merupakan tenaga medis yang perannya tidak dapat dikesampingkan dari semua bentuk pelayanan rumah sakit. Peran ini disebabkan karena tugas perawat mengharuskan kontak paling lama dengan pasien. Perawat rumah sakit di dominasi sebagian oleh tenaga kerja wanita, keterlibatan wanita akan membawa dampak terhadap peranan mereka dalam kehidupan keluarganya. Dengan sistem pelayanan 24 jam yang terbagi dalam tiga shift (pagi, siang dan malam) jika tidak diimbangi dengan pembagian kerja yang proporsional dengan kehidupan rumah tangga mereka dapat menimbulkan stres kerja yang akan mempengaruhi kinerja mereka dan berdampak pada mutu pelayanan yang diberikan.

Ketika perawat wanita melakukan peran dan tanggung jawabnya sebagai staf yang harus mengikuti peraturan di rumah sakit dengan mengikuti shift pagi, siang dan malam, sementara disisi lain keluarga menuntut untuk tetap secara penuh melakukan perannya dalam rumah tangga. Perawat sebagai tenaga profesional diminta untuk berkomitmen terhadap pekerjaan mereka sementara pada waktu bersamaan secara normatif mereka juga harus memberikan prioritas pada peran keluarga mereka (Cox \& Griffths, 2000). Kondisi seperti ini sering memicu terjadinya konflik-konflik yang terjadi dalam kehidupan perusahaan, bila tidak ditangani secara serius akan menimbulkan dampak yang sangat berarti bagi usaha pencapaian tujuan perusahaan, salah satunya adalah rendahnya kinerja karyawan secara keseluruhan akan mempengaruhi produktifitas perusahaan (Anorogo,1992).

Konflik peran inilah yang mesti diperhatikan sebagai faktor pembentuk terjadinya stres di tempat kerja, meskipun ada juga faktor-faktor lain dari luar. Tingginya tingkat stres psikologis sehubungan dengan peran yang dilakukan dialami bila individu seringkali bekerja keras memenuhi tuntutan pertama tersebut dan adanya gangguan dari peran kedua atau sebaliknya. Menurut Greenhaus dan Beutell (1985), terdapat bukti bahwa ketegangan antara keluarga dan aturan pekerjaan yang menunjukkan terdapatnya penurunan 
kesejahteraan karyawan secara psikologis maupun fisik yang dapat berujung stres. Konflik pekerjaan-keluarga yang mengakibatkan stres dipengaruhi oleh kondisi internal psikologis wanita ini sendiri, yang mana merasa cemas, bersalah dan mengganggap terlalu mementingkan diri sendiri.

Permasalahan lain yang dapat menimbulkan stres yaitu dukungan sosial dari orang-orang sekitar, baik keluarga, rekan kerja, maupun dengan atasan yang rendah. Dukungan sosial yang rendah akan mengganggu kenyamanan perawat dalam bekerja. Menurut House (2002) seseorang yang memiliki hubungan sosial yang baik maka dapat meredam stres yang terjadi dalam pekerjaan mereka, sehingga apabila seorang perawat memiliki dukungan sosial baik dari pasangan hidup/keluarga, atasan dan rekan kerja yang tinggi maka akan mengelola stres kerja dengan cara yang berbeda sehingga dapat memberikan dampak yang positif terhadap perawat tersebut, demikian sebaliknya jika dukungan sosialnya rendah maka perawat tersebut tidak dapat mengelola stres kerja dengan baik dan itu berakibat menurunnya kinerja perawat tersebut.

Permasalahan lainnya yang dapat menimbulkan stres adalah rendahnya kecerdasan emosional yang dimiliki individu. Seseorang yang memiliki kecerdasan emosional yang tinggi mampu mengelola stres yang dialaminya. Kecerdasan emosional adalah kemampuan seseorang dalam mengelola emosi agar lebih mampu menempatkan emosi pada porsi yang tepat, memilah dan mengatur suasana hati (Goleman, 2002). Pekerja medis seperti perawat mempunyai keterlibatan emosional yang tinggi dalam memberikan pelayanan. Ini dikarenakan perawat membutuhkan energi yang cukup besar untuk selalu bersikap sabar dan memahami orang lain dalam keadaan krisis, frustasi, ketakutan dan kesakitan.

Kesuksesan dari kinerja perusahaan bisa dilihat dari kinerja yang dicapai oleh karyawannya oleh sebab itu perusahaan menuntut agar para karyawannya mampu menampilkan kinerja yang optimal karena baik buruknya kinerja yang dicapai oleh karyawan akan berpengaruh pada kinerja dan keberhasilan perusahaan secara keseluruhan. Kinerja seorang perawat dapat dilihat dari mutu asuhan keperawatan yang diberikan pada pasien. Pada dasarnya yang dijadikan acuan dalam menilai kualitas pelayanan keperawatan adalah dengan menggunakan standar praktek keperawatan. Tenaga perawat 
merupakan tenaga yang paling banyak dan paling lama kontak dengan pasien, maka kinerja perawat harus selalu ditingkatkan dalam pemberian asuhan keperawatan, agar nantinya didapatkan mutu pelayanan yang baik serta pasien merasa puas terhadap kinerja perawat.

\section{Metodologi}

Penelitian ini termasuk dalam penelitian penjelasan (explanatory research). Tujuan dilakukannya penelitian kuantitatif ini untuk mengetahui pengaruh konflik pekerjaan-keluarga, dukungan sosial dan kecerdasan emosional terhadap stress kerja dan kinerja perawat wanita di RSD dr. Soebandi Jember. Populasi pada penelitian ini adalah keseluruhan perawat wanita di RSD dr. Soebandi Jember. Berkaitan dengan digunakannya uji model dengan Structural Equation Modelling (SEM) dengan menggunakan AMOS, Augusty Ferdinand. (2006) menyatakan jumlah responden yang ideal untuk setiap indikator adalah 5-10. Pada penelitian ini terdapat 24 indikator, maka jumlah responden yang dijadikan sampel sebanyak $120(=24 \times 5)$. Dalam penelitian ini Dalam penelitian ini, teknik pengambilan sampel yang digunakan adalah teknik purposive sampling, yakni pengambilan sampel tersebut terbatas pada jenis orang tertentu dan dapat memberikan informasi yang diinginkan entah karena mereka adalah satu-satunya yang memilikinya atau memenuhi beberapa kriteria yang ditentukan oleh peneliti (Sekaran, 2003). Adapun kriteria yang dimaksud yaitu: (1) Perawat wanita yang telah menikah; dan (2) Perawat wanita yang memiliki masa kerja $\geq 1$ tahun.

Skala pengukuran data pada penelitian ini menggunakan skala Likert dengan dengan lima tingkat preferensi jawaban dengan skor masing-masing 15. Metode analisis yang digunakan yaitu analisis SEM (Structural Equation Model) dengan alat perangkat lunak AMOS. Sebagai salah satu teknik analisis multivariat, SEM memungkinkan dilakukannya analisis terhadap serangkaian hubungan secara simultan sehingga memberikan efisiensi. Penggunaan SEM memungkinkan peneliti untuk menguji validitas dan reliabilitas instrumen penelitian, mengkonfirmasi ketepatan model sekaligus menguji pengaruh suatu variabel terhadap variabel lain. 


\section{Hasil dan Pembahasan}

\section{$\underline{\text { Pengaruh Konflik Pekerjaan-Keluarga terhadap Stres Kerja }}$}

Hasil penelitian menunjukkan bahwa konflik pekerjaan-keluarga berpengaruh signifikan dan positif terhadap stres kerja perawat wanita RSD dr. Soebandi Jember. Berdasar hasil analisis, nilai signifikansi yang dihasilkan adalah mendekati 0 atau sesuai standart deviasi $<0,05$. Hal tersebut menunjukkan bahwa semakin tinggi tingkat konflik pekerjaan-keluarga yang dialami perawat akan berdampak terhadap tingkat stres kerja perawat wanita di RSD dr. Soebandi Jember. Begitu pula sebaliknya, semakin rendah tingkat konflik pekerjaan-keluarga maka semakin rendah pula tingkat stres kerja yang dialami perawat wanita. Dengan demikian, hipotesis penelitian yang pertama, yakni konflik pekerjaan-keluarga berpengaruh signifikan dan positif terhadap stres kerja perawat wanita RSD dr. Soebandi Jember dinyatakan diterima. Hasil penelitian ini mendukung penelitian Cristian \& Rodney (2011) yang berjudul “ $A$ study of work-family conflict, family-work conflict and the contingent effect of self-efficacy of retail salespeople in a transitional economy".

Konflik pekerjaan-keluarga adalah suatu bentuk konflik peran dalam diri seseorang yang muncul karena adanya tekanan peran dari pekerjaan yang bertentangan dengan tekanan dari peran keluarga. Adanya tuntutan untuk mendukung ekonomi rumah tangga menjadi salah satu alasan bagi wanita untuk bekerja. Pada perempuan yang bekerja, seperti perawat wanita, mereka dihadapkan pada banyak pilihan yang ditimbulkan oleh perubahan peran dalam masyarakat, di satu sisi mereka harus berperan sebagai ibu rumah tangga yang tentu saja bisa dikatakan memiliki tugas yang cukup berat dan sisi lain mereka juga harus berperan sebagai wanita karir. Keinginan untuk menjalankan kedua peran tersebut dengan sempurna, terkadang saling bertentangan satu dengan lain, sehingga dapat menimbulkan konflik pada perawat wanita. Dengan demikian semakin besar konflik peran ganda pada perawat wanita, maka akan semakin besar pula kecenderungan untuk mengalami stres kerja.

Konflik antara pekerjaan dan keluarga yang dialami perawat ini dapat mempengaruhi pekerjaan dan dapat menjadi gangguan bagi mereka, sehingga menyebabkan penurunan kinerja. Dampak dari keadaan ini tidak secara langsung dapat terlihat, tetapi secara nyata keadaan tersebut mempengaruhi 
emosi perawat. Hal ini serupa dengan pernyataan Handoko (2011) yang menjelaskan bahwa stres adalah suatu kondisi ketegangan yang mempengaruhi emosi, proses berfikir dan kondisi seseorang. Ketegangan ini muncul ketika perawat merasakan kekhawatiran, kesulitan dan masalah yang mereka hadapi terasa berat dan tidak dapat ditoleransi lagi. Seorang perawat wanita seharusnya mampu menyeimbangkan waktu antara pekerjaan dan keluarga sehingga tidak terjadi konflik pekerjaan-keluarga dan akibatnya yang menimbulkan stres. Seorang perawat yang selalu melayani berbagai tipe pasien dengan berbagai sifat dan karakteristik yang berbeda-beda perlu memiliki kondisi fisik dan psikis yang baik sehingga dapat melayani pasien dengan baik pula.

Perawat yang berada di RSD dr. Soebandi Jember memiliki jadwal jaga yang sudah ditentukan yaitu antara pagi, sore dan malam, tetapi kenyataannya yang sering terjadi di dalam dunia kerja banyak situasi yang membuat perawat tidak dapat menghindari tugas dan perannya, dan mengharuskan mereka untuk mengorbankan salah satu perannya untuk memenuhi peran yang lain. Profesionalitas yang dijunjung tinggi terkadang membuat perawat yang sudah menikah menomer duakan masalah keluarga dan lebih fokus pada pekerjaan mereka atau sebaliknya. Hal ini sesuai dengan hasil penelitian Cinnamon dan Rich (2002) menunjukkan wanita yang bekerja ternyata lebih sering mengalami konflik dan permasalahan serta lebih menekankan pentingnya permasalahan keluarga dibanding pekerjaan, ketika keluarga sebagai domain yang paling penting bagi kebanyakan wanita.

\section{Pengaruh Konflik Pekerjaan-Keluarga terhadap Kinerja}

Merujuk pada hasil penelitian bahwa konflik pekerjaan-keluarga berpengaruh signifikan dan negatif terhadap kinerja. Berdasar hasil analisis, nilai signifikansi yang dihasilkan adalah 0,038 atau sesuai standart deviasi < 0,05 . Hal ini menunjukkan bahwa semakin tinggi konflik yang timbul antara pekerjaan-keluarga, maka kinerja menjadi rendah. Begitu pula sebaliknya, jika konfli pekerjaan-keluarga rendah, maka kinerja akan tinggi. Demikian hipotesis yang kedua yakni konflik pekerjaan-keluarga berpengaruh signifikan dan negatif terhadap kinerja perawat wanita RSD dr. Soebandi Jember, dinyatakan diterima. Hasil penelitian ini didukung oleh penelitian dari Bernhard dan 
Florensia (2014) yang berjudul "Pengaruh Konflik Peran terhadap Kinerja Wanita Karir pada Universitas Sam Ratulangi Manado". Hasil dari penelitiannya menyatakan bahwa konflik peran berpengaruh signifikan terhadap kinerja.

Konflik pekerjaan-keluarga tersebut dialami oleh perawat wanita di RSD dr. Soebandi Jember. Perawat yang mengalami tingkat konflik tinggi melaporkan menurunnya kinerja karena merasa lebih dikuasai oleh pekerjaannya yang mengakibatkan tidak bisa memenuhi tanggung jawab terhadap keluarga, karena mengurangi kualitas kehidupan keluarganya. Rumah dan pekerjaan yang tumpah tindih dapat menurunkan kinerja. Misalnya, kesulitan dirumah dapat menyebabkan pekerja menghabiskan waktu pekerjaan menjadi kurang konsen dan terburu-buru. Oleh sebab itu, dengan semakin banyaknya tekanan dan tuntutan dalam kehidupan pekerjaan-keluarga maka kinerja seseorang di lingkungan pekerjaannya semakin rendah. Hal ini terjadi karena tekanan dan tuntutan yang berasal dari peran ganda seseorang menyebabkan tidak maksimalnya seseorang dalam menyelesaikan pekerjaannya.

\section{Pengaruh Dukungan Sosial terhadap Stres Kerja}

Hasil penelitian menunjukkan bahwa dukungan sosial berpengaruh signifikan dan negatif terhadap stres kerja perawat wanita RSD dr. Soebandi Jember. Berdasarkan hasil analisis, nilai signifikansi yang dihasilkan adalah sebesar 0,015 atau sesuai standart deviasi < 0,05. Ini artinya bahwa tingginya dukungan sosial yang didapat akan menyebabkan stres kerja menjadi rendah. Begitu juga sebaliknya, jika dukungan sosial rendah maka stres kerja akan semakin meningkat. Demikian hipotesis penelitian yang ketiga yakni dukungan sosial berpengaruh signifikan dan negatif terhadap stres kerja perawat wanita RSD dr. Soebandi Jember, dinyatakan diterima. Temuan penelitian ini sesuai dengan penelitian Tianan Yang et al. (2015) yang berjudul "Effects of CoWorker and Supervisor Support on Job Stres and Presenteeism in an Aging Workforce: A Structural Equation Modelling Approach". Hasil dari penelitian Tianan Yang et al (2015) menyatakan bahwa terdapat pengaruh yang signifikan antara rekan kerja dan atasan terhadap stres kerja.

Perawat di RSD dr. Soebandi Jember memiliki keleluasan dalam berkomunikasi dengan pimpinan, dokter, maupun perawat lainnya untuk 
mendiskusikan terkait perawatan pada pasien, sehingga jika perawat mengalami kesulitan dalam melakukan pekerjaannya dapat langsung ditemukan penyelesaian melalui diskusi yang dilakukan. Hal seperti ini selalu dijaga oleh para perawat untuk mengkondisikan iklim di tempat kerja selalu nyaman dan kondusif. Ini disebabkan karena perawat yang lebih sering menghadapi pasien dengan sifat dan karakteristik berbeda sehingga harus tetap terjaga kondisi fisik dan psikisnya dalam melayani pasien agar stres dan ketegangan terkendali. Pekerja yang memiliki dukungan sosial yang baik dalam dunia pekerjaan akan dapat bertahan dengan baik dari serangan stres yang ditimbulkan akibat beban pekerjaan yang berat. Dukungan sosial sebagai pertolongan atau bantuan yang diterima individu dari interaksinya dengan lingkungan. Dengan diterimanya dukungan sosial maka individu akan lebih sehat fisik dan psikisnya daripada individu yang tidak menerima dukungan sosial.

\section{Pengaruh Dukungan Sosial terhadap Kinerja}

Hasil penelitian menunjukkan bahwa dukungan sosial berpengaruh signifikan dan positif terhadap kinerja perawat wanita RSD dr. Soebandi Jember. Berdasar hasil analisis, nilai signifikansi yang dihasilkan adalah mendekati 0 atau sesuai standart deviasi $<0,05$. Dapat dijelaskan bahwa dukungan sosial yang diterima perawat tersebut tinggi maka mampu meningkatkan kinerja perawat RSD dr. Soebandi Jember. Begitu pula sebaliknya, bahwa jika dukungan sosial rendah, maka kinerja akan menurun. Demikian, hipotesis penelitian yang keempat yakni dukungan sosial berpengaruh signifikan dan positif terhadap kinerja perawat wanita RSD dr. Soebandi Jember, dinyatakan diterima. Hasil penelitian ini sesuai dengan penelitian Raeda Fawzi (2004) yang berjudul "Job Stres, Job Performance, and Social Support Among Hospital Nurses". Hasil dari penelitian Raeda Fawzi (2004) menyatakan bahwa dukungan sosial dari rekan kerja berpengaruh secara signifikan terhadap kinerja. Menurut Raeda, dukungan sosial dari rekan kerja mampu meningkatkan tingkat kinerja karyawan dan mampu menurunkan tingkat stres.

Pencapaian kinerja yang baik tanpa mendapatkan dukungan sosial sulit terwujud, dengan mendapatkan dukungan sosial karyawan mampu bekerja 
lebih bersemangat, lebih baik karena pada dasarnya manusia sebagai mahluk sosial yang membutuhkan dukungan dari orang lain. Dukungan sosial adalah suatu bentuk hubungan interpersonal dengan orang-orang yang ada di sekitar, yang didalamnya terdapat pemberian bantuan berupa empati yang diberikan melalui proses komunikasi dan kontak sosial. Pada akhirnya akan mendapat kesenangan dan penghargaan dari orang yang mendapatkan bantuan serta perasaan yang diperhatikan dari orang yang menerima bantuan atau dukungan. Keterlibatan keluarga, teman maupun atasan kerja dapat memberikan dukungan, khususnya bagi yang memiliki kebutuhan khusus dan tidak didapatkan dalam pekerjaan maupun tempat kerja. Dukungan dapat bersifat langsung maupun tidak langsung. Dukungan sosial mempengaruhi aspek psikologis sehingga karyawan dapat bekerja lebih tenang, loyal dan termotivasi dalam bekerja sehingga tercipta kinerja karyawan yang baik.

\section{Pengaruh Kecerdasan Emosional terhadap Stres Kerja}

Hasil penelitian menunjukkan bahwa kecerdasan emosional berpengaruh signifikan dan negatif terhadap stres kerja perawat wanita RSD dr. Soebandi Jember. Berdasar hasil analisis, nilai signifikansi yang dihasilkan adalah 0,023 atau sesuai standart deviasi < 0,05. Hasil penelitian ini memberikan gambaran bahwa kecerdasan emosional yang rendah, maka stres kerja akan meningkat. Begitu pula sebaliknya, jika kecerdasan emosional tinggi, maka stres kerja akan menurun. Demikian, hipotesis penelitian kelima yakni kecerdasan emosional berpengaruh signifikan dan negatif terhadap stres kerja perawat wanita RSD dr. Soebandi Jember, dinyatakan diterima. Penelitian ini sesuai dengan penelitian Kakali and Rita (2013) dalam "Relation between Emotional Intelligence and Job stres among engineer's at Managerial level at Public sector organization" yang melakukan penelitian pada insinyur di tingkat manajerial pada organisasi sector public menemukan hasil bahwa seseorang yang memiliki kecerdasan emosional level tinggi cenderung memiliki tingkat stres yang rendah.

Stres kerja banyak dialami oleh para pekerja di bidang pelayanan kemanusiaan, seperti halnya perawat. Hal ini berkenaan dengan besarnya keterlibatan emosional yang dapat menimbulkan tekanan yang cukup besar dalam diri pemberi layanan. Pekerja yang bekerja pada bidang pelayanan 
sosial membutuhkan energi yang cukup besar untuk selalu bersikap sabar dan memahami orang lain dalam keadaan krisis, frustasi, ketakutan dan kesakitan. Karena stres bisa terjadi pada siapa saja, dari golongan pekerjaan apapun termasuk perawat. Apalagi keperawatan itu sendiri merupakan suatu bagian yang mengambil peranan penting dalam suatu organisasi rumah sakit. Perawat dengan kecerdasan emosi yang tinggi, maka akan terbentuk sikap yang positif pula dengan bertindak secara positif dalam mengerjakan pekerjaan yang dijalani. Sehingga stres yang ada pada pekerjaan membantu perawat untuk memenuhi tuntutan pekerjaannya. Perawat menganggap tekanan atau kesulitan sebagai tantangan sehingga akan membuat perawat semakin meningkatkan performansi kinerjanya. Sebaliknya, apabila kecerdasan emosi rendah, maka akan terbentuk sikap yang negatif dengan bertindak secra negatif pula dalam mengerjakan pekerjaan yang dijalani. Stresor pada pekerjaan akan dianggap sebagai hambatan yang menyulitkan. Akibatnya perawat akan merasa terbebani sehingga rentan akan munculnya stres.

\section{Pengaruh Kecerdasan Emosional terhadap Kinerja}

Hasil penelitian menunjukkan bahwa kecerdasan emosional berpengaruh signifikan dan positif terhadap kinerja perawat wanita RSD dr. Soebandi Jember. Berdasarkan hasil analisis, nilai signifikansi yang dihasilkan adalah mendekati 0 atau sesuai standart deviasi $<0,05$. Artinya, bila karyawan dapat mengendalikan emosinya dalam bekerja, maka akan menghasilkan kinerja yang tinggi. Begitu juga sebaliknya, jika karyawan tidak mampu mengendalikan emosinya, maka kinerja akan rendah. Demikian, hipotesis penelitian yang keenam, yakni kecerdasan emosional berpengaruh signifikan dan positif terhadap kinerja perawat wanita RSD dr. Soebandi Jember, dinyatakan diterima. Penelitian ini sesuai dengn penelitian terdahulu yakni penelitian oleh Noorazzila et al (2014) yang berjudul "The Relationship between Emotional Intelligence and Job Performance of Call Centre Agents". Hasil dari penelitiannya adalah terdapat hubungan yang signifikan antara kecerdasan emosional dengan kinerja pada agen call center. Kecerdasan emosional sebagai kemampuan memantau dan mengendalikan perasaan sendiri dan serta menggunakan perasaan-perasaan itu untuk memandu pikiran dan tindakan dalam mengarahkan dan menggerakkan karyawan dalam 
meningkatkan kinerja akan berdampak terhadap pencapaian tujuan perusahaan, serta karyawan dapat mengatasi setiap kendala yang dihadapi dengan adanya kecerdasan emosional. Hal ini sesuai dengan pendapat Robbins (2008) kecerdasan emosional (emotional intelligence) adalah kemampuan seseorang untuk mendeteksi serta mengelola petunjuk-petunjuk dan informasi emosional. Orang-orang yang mengenal emosi-emosi mereka sendiri dan mampu dengan baik membaca emosi orang lain dapat menjadi lebih efektif dalam pekerjaan.

Adanya pengaruh kecerdasan emosional terhadap kinerja karyawan ini sangat beralasan karena pada dasarnya perawat di RSD dr. Soebandi Jember saat bekerja, mereka dapat menyadari kekuatan dan kelemahan mereka dalam menjalankan tugas atau menyelesaikan pekerjaan. Begitupun dalam pengendalian emosi, setiap hari karyawan dihadapkan dengan beban tugas silih berganti dan semuanya harus dikerjakan sesuai target, tak jarang hal ini dapat menyebabkan emosi jadi tidak stabil. Dalam penyelesaian pekerjaan, kemauan ataupun semangat dari karyawan untuk menyelesaikan tugas-tugas yang diberikan begitu sangat diperlukan, sehingga hal ini menjadi salah satu indikator penting dalam peningkatan kecerdasan emosional. Kemampuan untuk memahami kondisi orang lain serta kemampuan untuk berinteraksi (bekerja sama) dengan orang lain juga menjadi indikator penting pada variabel ini, karena apabila karyawan tidak mampu memahami kondisi orang lain dan tidak mampu untuk berinteraksi maupun bekerja sama dengan orang lain, yang bersangkutan akan menjadi orang yang pasif dan tidak akan puas dengan hasil kerjanya.

\section{Pengaruh Stres Kerja terhadap Kinerja}

Hasil penelitian menunjukkan bahwa stres kerja berpengaruh signifikan dan negatif terhadap kinerja perawat wanita RSD dr. Soebandi Jember. Berdasar hasil analisis, nilai signifikansi yang dihasilkan adalah 0,022 dimana sesuai dengan standart deviasi yaitu $<0,05$. Artinya, bahwa semakin tinggi stres kerja maka kinerja akan menurun. Begitu juga sebaliknya, jika stres kerja rendah, maka kinerja akan meningkat. Demikian, hipotesis penelitian yang ketujuh, yakni stres kerja berpengaruh signifikan dan negatif terhadap kinerja perawat wanita RSD dr. Soebandi Jember, dinyatakan diterima. Penelitian ini 
didukung oleh penelitian Yu_Chi Wu (2011) yang berjudul "Job Stres And Job Performance Among Employees In The Taiwanese Finance Sector: The Role Of Emotional Intelligence". Peneliti juga menemukan bahwa stres kerja berpengaruh signifikan terhadap kinerja.

Kebanyakan perawat wanita RSD dr. Soebandi Jember mengeluhkan target dan tuntutan tugas yang terlalu tinggi yang harus mereka jalankan setiap hari, sehingga terkadang waktu istirahat para perawat harus terabaikan dan berpindah ke waktu lain. Ini menjadi salah satu faktor dominan pembangkit stres yang dirasakan oleh para perawat. Setiap hari untuk perawat shift malam harus menjalankan tugas mulai dari pukul 20.00 malam hingga pukul 07.00 pagi melanjutkan kerja perawat shift pagi dan sore. Setiap langkah dan aktivitas penanganan pasien secara detail harus dicatat oleh setiap perawat sebagai salah satu bukti kerja dan perkembangan keadaan pasien yang ditangani. Bertanggung jawab sepenuhnya atas penanganan/perawatan yang diberikan kepada pasien yang ditangani juga menjadi beban tersendiri bagi para perawat, terlebih jika pasien yang ditangani lebih dari satu orang dan dalam keadaan yang sangat gawat. Keselamatan pasien menjadi yang utama untuk dipertanggung jawabkan oleh dokter dan terlebih perawat sebagai subyek layanan kesehatan yang lebih intens bertemu dengan para pasien.

Kondisi ini menuntut pergerakan yang super cepat dari para perawat yang rata-rata menangani lebih dari satu pasien setiap harinya. Bahkan pasien yang terus berdatangan hingga melampaui waktu istirahat. Tidak hanya itu saja, perawat juga mengeluhkan pekerjaan rutin yang diulang-ulang, setiap langkah harus ditulis, perpindahan perawat ke tempat lain, situasi akut yang sering terjadi, bahaya fisik yang mengancam seperti, tertusuk jarum suntik, terpapar sinar radiasi dan terinveksi virus. Kondisi ini menyebabkan perawat menjadi mudah mengalami stres kerja sehingga berakibat kinerja menurun.

\section{Kesimpulan}

Berdasarkan hasil pembahasan secara keseluruhan pada penelitian ini diperoleh kesimpulan bahwa: (1) Konflik pekerjaan-keluarga berpengaruh signifikan dan positif terhadap stres kerja perawat wanita RSD dr. Soebandi Jember. Hal ini menunjukkan semakin tinggi konflik pekerjaan-keluarga maka semakin tinggi pula stres kerja. Begitu pula sebaliknya, semakin rendah konflik 
pekerjaan-keluarga maka semakin rendah pula stres kerja yang dialami perawat wanita RSD dr. Soebandi Jember; (2) Konflik pekerjaan-keluarga berpengaruh signifikan dan negatif terhadap kinerja perawat wanita RSD dr. Soebandi Jember. Hal ini menunjukkan bahwa semakin tinggi konflik yang timbul antara pekerjaan dan keluarga akan mampu menurunkan kinerja perawat wanita RSD dr. Soebandi Jember. Begitu pula sebaliknya, jika konflik yang timbul rendah maka kinerja akan meningkat; (3) Dukungan sosial berpengaruh secara signifikan dan negatif terhadap stres kerja perawat wanita RSD dr. Soebandi. Ini artinya bahwa semakin tinggi dukungan sosial yang didapat oleh perawat wanita RSD dr. Soebandi Jember maka stres kerja akan menurun. Begitu juga sebaliknya, jika semakin rendah dukungan sosial, maka stres kerja akan meningkat; (4) Dukungan sosial berpengaruh signifikan dan positif terhadap kinerja perawat wanita RSD dr. Soebandi Jember. Dapat dijelaskan bahwa dukungan sosial yang diterima perawat tersebut tinggi maka mampu meningkatkan kinerja perawat wanita RSD dr. Soebandi Jember. Begitu pula sebaliknya, bahwa jika dukungan sosial rendah, maka kinerja akan menurun; (5) Kecerdasan emosional berpengaruh signifikan dan negatif terhadap stres kerja. Hasil penelitian ini memberikan gambaran bahwa jika kecerdasan emosional yang dimiliki perawat wanita RSD dr. Soebandi Jember tinggi maka stres kerja akan menurun. Begitu juga sebaliknya, jika kecerdasan emosional rendah maka stres kerja akan meningkat; (6) Kecerdasan emosional memiliki pengaruh yang signifikan dan positif terhadap kinerja perawat wanita di RSD dr. Soebandi Jember. Artinya, bila karyawan dapat mengendalikan emosinya dalam bekerja, maka akan menghasilkan kinerja yang tinggi; dan (7) Terdapat pengaruh yang signifikan dan negatif atara stres kerja terhadap kinerja perawat wanita RSD dr. Soebandi Jember. Artinya, bahwa semakin tinggi stres kerja perawat wanita di RSD dr. Soebandi Jember, maka akan mengalami penurunan kinerja. Begitu pula sebaliknya, jika stres kerja rendah maka kinerja mengalami peningkatan.

\section{Saran}

Berdasarkan hasil penelitian dan kesimpulan di atas, maka dapat dikemukakan saran antara lain: (1) Diharapkan hasil penelitian dapat menjadi bahan evaluasi peningkatan kinerja bagi manajemen keperawatan di RSD dr. 
Soebandi Jember dalam upaya penurunan konflik pekerjaan-keluarga dan stress kerja pada perawat wanita sehingga terjadi peningkatan kinerja perawat yang berdampak pada peningkatan mutu pelayanan di rumah sakit; (2) Penelitian selanjutnya dapat menambahkan opsi posisi jabatan dalam karakteristik responden agar diperoleh gambaran bagaimana posisi jabatan juga mempengaruhi tingkat konflik pekerjaan keluarga, stres kerja, dukungan sosial maupun kecerdasan emosional; dan (3) Penelitian selanjutnya dapat membedakan sampel antara rumah sakit pemerintah dengan rumah sakit swasta, sehingga dapat diketahui perbedaan tingkat konflik-pekerjaan dan stres kerja.

\section{Daftar Referensi}

Anoraga, Panji, 1992, Psikologi Kerja, Penerbit PT. Rineka Cipta, Jakarta.

Augusty, Ferdinand. 2006. Metode Penelitian Manajemen.Semarang: Badan Penerbit Universitas Diponegoro.

Bernhard et al. 2014. Pengaruh Konflik Peran terhadap Kinerja Wanita Karir pada Universitas Sam Ratulangi Manado. Jurnal EMBA.

Cinnamon, R \& Rich, Y. 2002. Gender Differences in The Importance of Work and Family Roles : Implications for work-family conflict. Sex Roles, 47, 531-541.

Cox, T., Griffiths, A. \& Rial-González, E. (2000). Research on work-related stres. European Agency for Safety \& Health at Work. Luxembourg: Office for Official Publications of the European Communities.

Cristian Chelariu, Rodney Stamp. 2011. A study of work-family conflict, family-work conflict and the contingent effect of self-efficacy of retail salespeople in a transitional economy. European Journal of marketing vol 45 pp 1660-1679.

Goleman, Daniel. 2002. Working With Emotional Intelligence (terjemahan). PT. Gramedia Pustaka Utama. Jakarta.

Greenhaus, Beutell, 1985, What is the meaning of work-family conflict in terms of interrole conflict in work-family research.

Handoko, T. H. (1993), Manajemen Personalia dan Sumber Daya Manusia, Liberty,Yogyakarta.

Kakali Goswami \& Rita Rani. 2013. Relation between Emotional Intelligence and Job stres among engineer's at Managerial level at Public sector organization. IOSR Journal of Humanities and Sosial Science.

Noorazzila et al. 2014. The Relationship Beteen Emotional Inteligence and Job Performance of Call Centre Agents. Journal of Social and Behavioral Sciences. 
Raeda, F. 2004. Job Stres, Job Performance, and Social Support among Hospital Nurse. Journal of Nursing Scholarship.

Robbins, Stephen. P. 2006.Perilaku Organisasi (alih bahasa Benjamin Molan),Edisi Bahasa Indonesia,Klaten: PT INTAN SEJATI.

Sekaran, U. 2003. Research Methods for Business : A Skill Building Approach $2^{\text {nd }}$ Edition, John Wiley and Son. New York.

Tianan et al. 2015. Effects of Co-Worker and Supervisor Support on Job Stres and Presenteeism in an Aging Workforce:A Structural Equation Modelling Approach. International Journal of Environment.

Yu-Chi Wu. 2011. Job Stres And Job Performance Among Employees In The Taiwanese Finance Sector: The Role Of Emotional Intelligence. Journal of Social Behaviour and personality. 